\title{
INFLUENCE OF ZINC AND SOME COMMERCIAL PRODUCTS ON TRAMADOL AND APETRYL DETECTION IN HUMAN URINE SAMPLES
}

\author{
Shereen A. El-Khateeb ; Manar H. Arafa \\ Department of forensic medicine \&clinical toxicology \\ Faculty of medicine- zagazig university- Egypt
}

Corresponding author: Shereen Ahmed Elkhateeb , Forensic Medicine and Clinical Toxicology, Faculty of Medicine, Zagazig University- Egypt

E-mail: sheren_elkhateb2001@yahoo.com

\begin{abstract}
Urine drug testing plays an important role in detecting licit and illicit drug use. Adulteration of urine samples have been employed to disrupt these drug tests. Recently, zinc sulfate was used as an effective adulterant to bypass drug testing. Aim of the work: The aim of the current study was to evaluate the effect of zinc sulfate and some adulteration methods on detection of tramadol and apetryl in urine and their effects on the validity tests. Method: Tramadol and apetryl were added to urine sample that were obtained from a healthy, drug-free subject to yield samples of urine containing tramadol and apetryl with concentrations (200 ng/ ml \& $400 \mathrm{ng} / \mathrm{ml}$ ). Visine eye drop, zinc sulfate and lemon were added to these samples as well as dilution was done. These samples were tested for their ability to generate false negative results for the immunoassay test screen. Results: All adulterated urine samples as regard both drugs generated false negatives results. PH paper test showed more acidic PH with lemon juice while visine, zinc sulfate and dilution gave light green coloration indicating slightly acidic PH. Specific gravity showed increase of specific gravity for urine adulterated with lemon but decrease in diluted urine. Conclusion: There are needs to a more effective and efficient approach to urinalysis due to the false negatives that can result from adulteration of urine samples.
\end{abstract}

Keywords: Drug abuse, Tramadol, Apetryl, Urine adulteration. 


\section{INTRODUCTION}

Drug abuse is one of the major public health problems in the world. It affects both the general population and the government. It affects young people in their productive years leading to many problems such as social maladaptation، decreased work productivity and job loss (AbdelGawad, 2008; Lee et al., 2013).

Over the past few decades, employee drug testing has become a common business practice in the world workplace (Walsh, 2008). False positive results of immunoassays may lead to serious medical, social or legal consequences. There are common areas for drug testing such as preemployment and random testing, athletics, the military fields, criminal and legal situations as post-accident testing, rehabilitation tests. Drug tests misinterpretation can have dangerous consequences, like risk of prison sentence, unjust termination from a job, inappropriate exemption from a sporting event, and inappropriate medical treatment in emergency cases (Moeller et al., 2008).

Humans tend to mask their illicit use of drugs or to change the chemistry of the urine sample to prevent their detection, through the use of adulterants. Drug testing protocols may vary depending on the agency and the funding available per sample. Still urine analysis for drug screening is the most common, as it has a large detection window for drugs of abuse, it is relatively inexpensive to perform especially for larger companies, and there is minimum sample preparation which makes it easier to screen for drugs than other biological matrices like blood or hair (Huestis et al., 1995; Verstraete 2004).
The main drawback of using urine as the sampling medium is the potential for the sample to be tampered with or adulterated prior to screening. To elude a positive result, many individuals will adulterate their urine sample using commercially available products (eg, bleach,Drano®, eye drops) that are easily carried into drug facilities in small containers. These adulterants may produce a false negative on immunoassay-based drug prescreenings (Cody and Schwarzhoff, 1989; Fu, 2016). These products are classified as invitro urinary adulterants, as the product is added to the sample after it is expelled from the body (Dasgupta 2007).

The adulteration of urine samples is of particular concern because a false negative result from drug screening analysis will lead to the sample not being submitted for subsequent analysis by a confirmatory technique, ie, gas chromatography-mass spectrometry (GC-MS) or liquid chromatography-mass spectrometry(LC-MS) (Schütz et al., 2006; Grange et al., 2014).

Tramax (Tramadol) is an opioid pain medication used to treat mild-severe pain, both acute and chronic (Grond and Sablotzki, 2004). Tramadol may be quantified in blood, plasma or serum to monitor for abuse, confirm a diagnosis of poisoning or assist in the forensic investigation of a sudden death (Karhu et al., 2007, Tjäderborn et al., 2007). It is excreted via the kidney. Thirty per cent (30\%) of the drug is excreted through the kidneys in an unchanged manner. and about $60 \%$ in the form of free and conjugated metabolites (Grond \& Sablotzki, 2004).

Clonazepam is structurally in the benzodiazepine class with sedative, anticonvulsant, and anxiolytic effects, 
but their prevalence in drug abuse and drug overdoses has long been recognized (Nordal et al., 2015).

Clonazepam is highly metabolized, with less than $2 \%$ unchanged clonazepam being excreted in the urine (Drug Bank).

Urinary concentrations of the benzodiazepines more than $200 \mathrm{ng} / \mathrm{ml}$ are most likely due to abuse not due to a prescribed intake under strict medical surveillance. So, the calibration standard and cutoff concentration for a positive result was set at $200 \mathrm{ng} / \mathrm{ml}$ (Needleman and Porvaznik,(1995).

So, the aim of the current study is to evaluate the effect of zinc sulfate and some adulteration methods on detection of tramadol and apetryl in urine and their effects on the validity tests.

\section{MATERIALS AND METHODS}

The study was performed at Forensic medicine and Clinical Toxicology Lab, department of Forensic Medicine and Clinical Toxicology, Faculty of Medicine, Zagazige University.

\section{Sampling:}

Urine (about $500 \mathrm{~mL}$ ) was collected in a clean glass container at different times from a single healthy volunteer with no history of previous drug abuse or any known medical conditions after consent. Negativity of this urine for tramadol and apetryl was confirmed.

\section{Materials and reagents:}

1. Tramadol capsules were purchased from Hi Pharm for Manufacturing Drugs and Chemicals Egypt
2. Apetryl tablets (Clonazepam) were purchased from Multi Apex for Pharmaceutical Industries.

3. Zinc sulfate, was obtained from chemical industries developmental (CID) Egypt.

4. Visine eye drops Tetrahydrozoline $\mathrm{HCl}$ purchased from Johnson \& Johnson.

5. Lemon juice was freshly prepared. prepared.

6. Distilled water was freshly

7. Abon Biopharm Multi-Drug Screen used for qualitative detection of tramadol and benzodiazepins in urine. The cutoff value for positive result is $(200 \mathrm{ng} / \mathrm{mL})$ for both of them.

\section{Methods:}

- Preparation of samples:

\section{1- Preparation of zinc solution}

Zinc sulfat was massed to produce a $15 \mathrm{mg} / \mathrm{mL}$ concentration of zinc when added to the sample. Zinc solutions were vortexed for one minute to promote dissolution of the salt.

2- Preparation of tramadol (200 $\mathrm{ng} / \mathrm{ml} \& 400 \mathrm{ng} / \mathrm{ml}$ )

A Tramadol capsule (50 mg) was dissolved in $50 \mathrm{~mL}$ distilled water to produce $1 \mathrm{mg} / \mathrm{mL}$ tramadol solution. Then $1 \mathrm{ml}$ was taken from the above solution and added to $1000 \mathrm{ml}$ distilled water to obtain concentration of 1000 ug/ $1000 \mathrm{ml}$. now we have tramadol concentration of $1 \mathrm{ug} / \mathrm{ml}$ or $1000 \mathrm{ng} /$ $\mathrm{ml}$. This original solution was diluted with distilled water to generate a 200ng/ml tramadol solution. The dilution was performed using the dilution formula: 


\section{$\mathrm{C} 1 \mathrm{~V} 1=\mathrm{C} 2 \mathrm{~V} 2$.}

Where $\mathrm{C} 1=$ the known concentration, $\mathrm{C} 2=$ the concentration needed to be prepared, $\mathrm{V} 1=$ the volume needed from the prepared solution, $\mathrm{V} 2=$ the volume needed to be prepared:

$(1000 \mathrm{ng} / \mathrm{mL}$ tramadol $)(\mathrm{V} 1)=$ (200 ng/ ml tramadol) (20ml)

$$
\mathrm{V} 1=4 \mathrm{ml}
$$

So, we need $4 \mathrm{ml}$ of tramadol solution and put them in a graduated baker and complete it to $20 \mathrm{ml}$ to get a tramadol solution with concentration of $200 \mathrm{ng} / \mathrm{ml}$. The same formula was used to get tramadol solution with concentration of $400 \mathrm{ng} / \mathrm{ml}$

\section{3- Preparation of apetryl $\mathrm{ng} / \mathrm{ml} \& 400 \mathrm{ng} / \mathrm{ml}$ ):}

Two mg tablet of apetryl was dissolved in $2 \mathrm{~mL}$ distilled water to produce $1 \mathrm{mg} / \mathrm{mL}$ apetryl solution. Then $1 \mathrm{ml}$ was taken from the above solution and added to $1000 \mathrm{ml}$ distilled water to obtain concentration of $1 \mathrm{mg} / 1000 \mathrm{~mL}$ which is equal to 1000 ug/ $1000 \mathrm{ml}$. Now we have apetryl concentration of $1000 \mathrm{ng} / \mathrm{ml}$. This original solution was diluted with distilled water to obtain $40 \mathrm{ml}$ apetryl solution with concentration of 200ng/ml and another $40 \mathrm{ml}$ apetryl with dilution $400 \mathrm{ng} / \mathrm{ml}$. The dilution was performed using the above mentioned dilution formula.

- Specimen Integrity Tests for all adulterated urine specimens.

1- PH analysis (normal range 4-8).

2-Determination of specific gravity (normal range: 1.005-1.025).
3- Aspect of urine (normally appears clear).

\section{Grouping:}

Urine samples were divided into aliquots ( $3 \mathrm{~mL}$ each) in clean test tubes and these samples were further divided into:

Group I: (Tramadol group) further subdivided into 2 subgroups

\section{Group Ia:}

Five aliquots of urine samples and to each of them $1 \mathrm{ml}$ tramadol 200ng/ $\mathrm{ml}$ was added. The first sample was labeled Ia (positive control). Then the other 4 samples, the following adulterants were added to each one as follow:

- Group Ia.1: 1mL visine eye drops was added.

- Group Ia.2: zinc sulfate $15 \mathrm{mg} / \mathrm{dl}$ was added.

- Group Ia.3: $1 \mathrm{ml}$ of concentrated lemon juice.

- Group Ia.4: $10 \mathrm{~mL}$ distilled water was added to evaluate effect of dilution.

\section{Group Ib:}

Five aliquots of urine samples and to each of them $1 \mathrm{ml}$ tramadol 400ng/ $\mathrm{ml}$ was added. The first sample was labeled Ib (positive control). Then the other 4 samples, the following adulterants were added to each one as follow:

- Group Ib.1: $1 \mathrm{~mL}$ visine eye drops was added.

- Group Ib.2: zinc sulfate $15 \mathrm{mg} / \mathrm{dl}$ was added. 
- Group Ib.3: $1 \mathrm{ml}$ of concentrated lemon juice.

- Group Ib.4: $10 \mathrm{~mL}$ distilled water was added to evaluate effect of dilution.

Group II (apetryl group): was further subdivided into 2 subgroups

\section{Group IIa:}

Five aliquots of urine samples and to each of them $1 \mathrm{ml}$ apetryl 200ng/ $\mathrm{ml}$ was added. The first sample was labeled IIa (positive control) .Then the other 4 samples, the following adulterants were added to each one as follow:

- Group IIa.1: $1 \mathrm{~mL}$ visine eye drops was added.

- Group IIa.2: zinc sulfate $15 \mathrm{mg} / \mathrm{dl}$ was added.

- Group IIa.3: $1 \mathrm{ml}$ of concentrated lemon juice.

- Group IIa.4: $10 \mathrm{~mL}$ distilled water was added to evaluate effect of dilution.

\section{Group IIb:}

Five aliquots of urine samples and to each of them $1 \mathrm{ml}$ apetryl 400ng/ $\mathrm{ml}$ was added. The first sample was labeled IIb (positive control). Then the other 4 samples, the following adulterants were added to each one as follow:

- Group IIb.1: $1 \mathrm{~mL}$ visine eye drops was added.

- Group IIb.2: zinc sulfate $15 \mathrm{mg} / \mathrm{dl}$ was added.

- Group IIb.3: $1 \mathrm{ml}$ of concentrated lemon juice.
- Group IIb.4: $10 \mathrm{~mL}$ distilled water was added to evaluate effect of dilution.

\section{Group III (Control group)}

Five aliquots of urine samples, the first sample was labeled III (used as negative control). Then the other 4 samples, the following adulterants were added to each one as follow:

- Group III 1: $1 \mathrm{~mL}$ visine eye drops was added.

- Group III 2: zinc sulfate $15 \mathrm{mg} / \mathrm{dl}$ was added.

- Group III 3: $1 \mathrm{ml}$ of concentrated lemon juice.

- Group III 4: $10 \mathrm{~mL}$ distilled water was added to evaluate effect of dilution.

\section{Competitive immunoassay analytical method:}

Drug detection is based on the principle of competitive immunochemical reaction. The nitrocellulose strips are impregnated with a chemically labeled drug conjugate in the test region, which is adjacent to a pad containing colored antibody colloidal gold conjugate. During the test, the urine sample migrates upward and hydrates the antibody-colloidal gold conjugate. The mixture then chromatographically migrates along the membrane by capillary action to the immobilized drug conjugate band on the test region. If the cross-reacting drug analyte is present in the urine, it competes with the drug conjugate for a limited number of antibody binding sites. In the absence of drugs in the urine sample, the colored antidrug antibody chromatographically migrates to the immobilized drug conjugated zone to from a visible line as the antibody 
complexes with the drug conjugate. When a sufficient concentration of drug analyte is present in the urine, the antibody binding sites will become saturated and prevent attachment of the drug conjugate to the test trip. So, the presence of the line on the test region means a negative result for the corresponding drug class, and the absence of the test line on the test

\section{RESULTS}

\section{- PH estimation:}

PH for urine samples was evaluated and results were showed in figs. $(1,2)$. When we added the adulterants and did dilution for urine samples of control group (III) the results showed orange coloration of $\mathrm{PH}$ paper test gave (about 4) on the scale with lemon juice, while visine, zinc sulfate and dilution gave light green coloration of $\mathrm{PH}$ paper test meaning (about 5-6) on the scale. When we added tramadol in both region denote a positive result for the drug. Any faint line in the test region indicates a negative result. A visible line generated by a different antigen antibody reaction is also present at the control region of the test strip to serve as a built-in control. If the control line does not appear after the test, the result is invalid.

concentrations $(200,400 \mathrm{ng} / \mathrm{ml})$ to urine, the PH test paper has been got light green coloration which is the same coloration of blank urine meaning ( about 6) on the scale and when added apetryl in both concentrations (200,400 ng/ml) ) to urine, the $\mathrm{PH}$ test paper has been got green coloration the meaning ( about 7) on the scale.

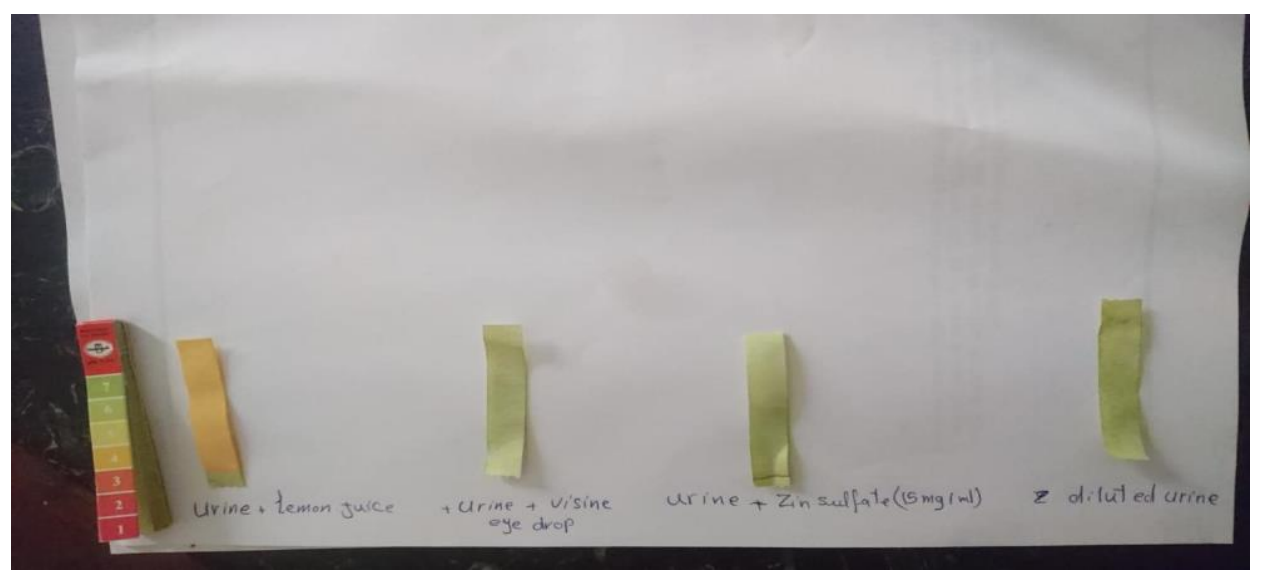

Fig 1: PH test paper of adulterated urine samples. 


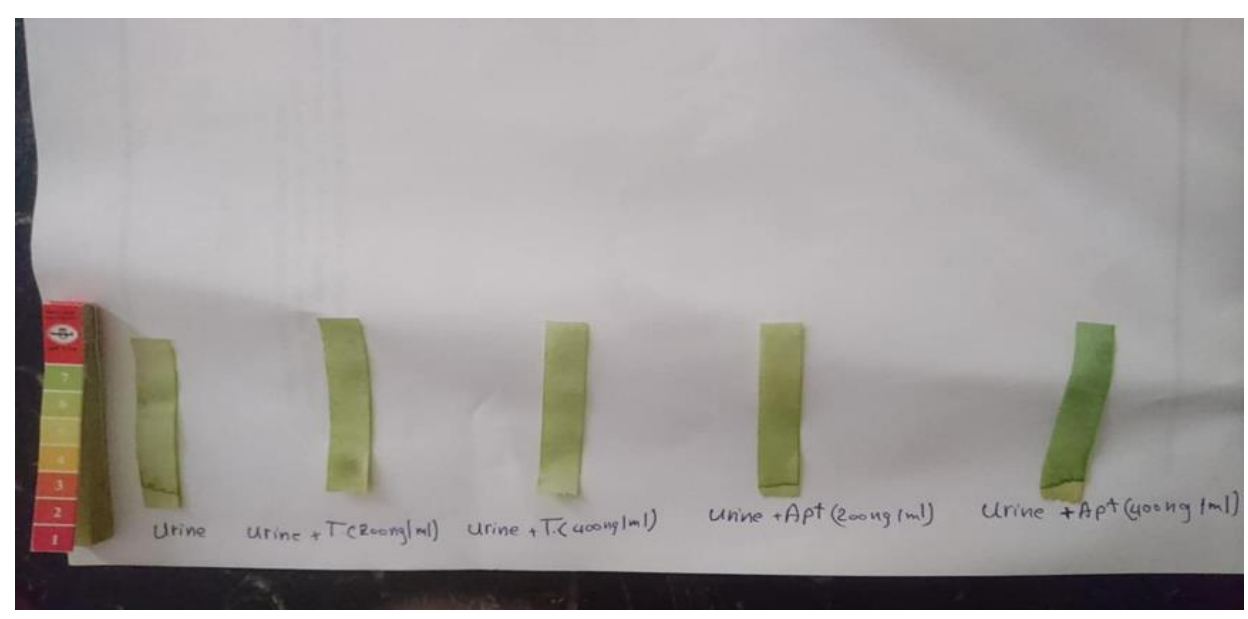

Fig 2: PH test paper of urine containing tramadol and apetryl in both concentrations $(200,400 \mathrm{ng} / \mathrm{ml})$

- Specific measurements:

Specific gravity for urine samples was evaluated by measuring it using combi screen kits (fig. 3) and results were showed in (table 1). It showed no changes in the specific gravity readings regarding urine samples adulterated with zinc sulphate and visine as both of them recoded 1.025 ( ref. range 1.005-1.025), while samples of urine adulterated with lemon showed increase of specific gravity reading. On other hand there was decrease in reading of diluted urine (1.015).

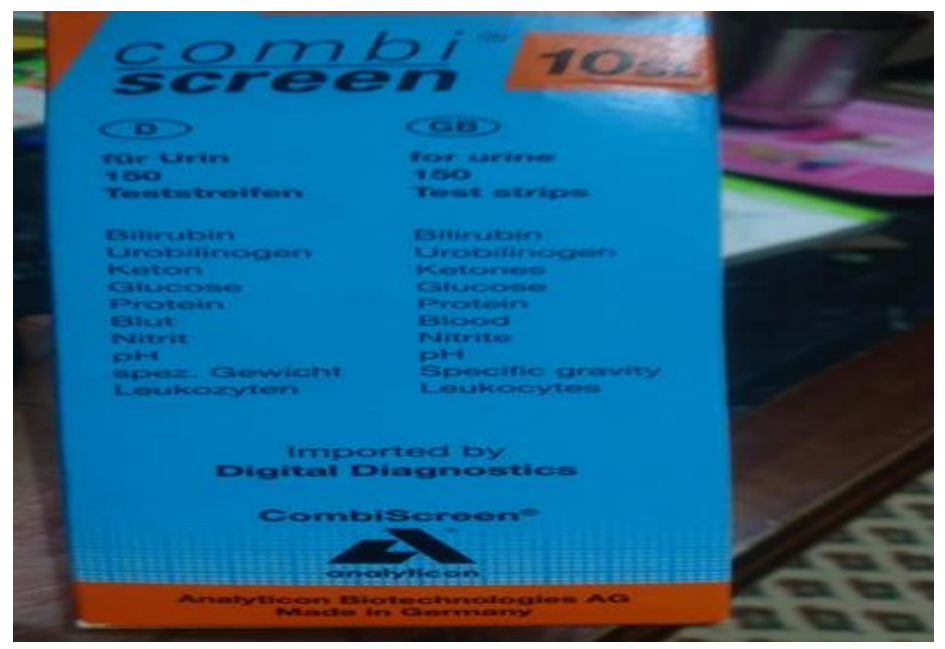

(Fig. 3): Combi screen kits for measuring specific gravity 
Table (1): specific gravity readings of negative control urine specimen and adulterated urine samples.

\begin{tabular}{|l|c|}
\hline Group & Sp. Gravity \\
\hline III (-ve control) & 1.025 \\
\hline III $_{1}$ (zinc sulphate) & 1.025 \\
\hline III $_{2}$ (visine) & 1.025 \\
\hline $\mathrm{III}_{3}$ (lemon) & 1.030 \\
\hline $\mathrm{III}_{4}$ (dilution) & 1.015 \\
\hline
\end{tabular}

\section{- Urine aspect:}

In this study when we added adulterants to urine, we observed the following:

Turbidity of urine with $\mathrm{ZnSo} 4$ and light yellow color with dilution while no changes observed in urine aspect with visine and lemon samples.

\section{- Drug of abuse test cards:}

Group I (Tramadol): Urine samples of tramadol in both concentrations Ia and Ib (200, 400 $\mathrm{ng} / \mathrm{ml}$ ) showed positive results (table 2), (figure 4). While all other urine samples which were adulterated with visine $\left(\mathrm{Ia}_{1}\right.$ and $\left.\mathrm{Ib}_{1}\right)$, zinc sulfate $\left(\mathrm{Ia}_{2}\right.$ and $\left.\mathrm{Ib}_{2}\right)$, lemon ( $\mathrm{Ia}_{3}$ and $\mathrm{Ib}_{3}$ ), as well as diluted samples ( $\mathrm{Ia}_{4}$ and $\mathrm{Ib}_{4}$ ) showed negative results (table 2) (figs 5, 6). 
Table (2): Results of tramadol detection by drug of abuse test cards in urine samples of all groups.

\begin{tabular}{|c|c|c|c|c|c|}
\hline $\begin{array}{l}\text { Group(Ia) } \\
\text { Tramadol } \\
\text { (200ng/ml) }\end{array}$ & result & $\begin{array}{l}\text { Group(Ib) } \\
\text { Tramadol } \\
(400 \mathrm{ng} / \mathrm{ml})\end{array}$ & Result & $\begin{array}{l}\text { Group(III) } \\
\text { (Control) }\end{array}$ & Result \\
\hline I a & $+v e$ & I b & + ve & III (-ve control) & -ve \\
\hline $\mathbf{I} \mathbf{a}_{1}$ & -ve & I $\mathbf{b}_{1}$ & -ve & III $_{1}$ & -ve \\
\hline $\mathbf{I} \mathbf{a}_{2}$ & -ve & I $\mathbf{b}_{2}$ & -ve & $\mathrm{III}_{2}$ & -ve \\
\hline $\mathbf{I} \mathbf{a}_{3}$ & -ve & I $\mathbf{b}_{3}$ & -ve & $\mathrm{III}_{3}$ & -ve \\
\hline I $\mathbf{a}_{4}$ & -ve & I $\mathbf{b}_{4}$ & -ve & $\mathrm{III}_{4}$ & -ve \\
\hline
\end{tabular}

Group II (Apetryl): Urine samples of apetryl in both concentrations IIa and IIb (200, 400 $\mathrm{ng} / \mathrm{ml}$ ) showed positive results (table 3) (fig. 7) while all other urine samples which were adulterated with visine (IIa 1 and $\mathrm{IIb}_{1}$ ), zinc sulfate ( $\mathrm{IIa}_{2}$ and $\mathrm{IIb}_{2}$ ), lemon ( $\mathrm{IIa}_{3}$ and $\mathrm{IIb}_{3}$ ), as well as diluted samples ( $\mathrm{IIa}_{4}$ and $\mathrm{IIb}_{4}$ ) showed negative results (table 3) (figs 8, 9). 
Table (3): Results of apetryl detection by drug of abuse test cards in urine samples of all groups.

\begin{tabular}{|c|c|c|c|c|c|}
\hline $\begin{array}{l}\text { Group(IIa) } \\
\text { Apetryl } \\
\text { (200ng/ml) }\end{array}$ & result & $\begin{array}{l}\text { Group(IIb) } \\
\text { Apetryl } \\
(400 \mathrm{ng} / \mathrm{ml})\end{array}$ & Result & $\begin{array}{l}\text { Group(III) } \\
\text { (Control) }\end{array}$ & Result \\
\hline II a & $+v e$ & II b & $+v e$ & $\begin{array}{l}\text { III (-ve } \\
\text { control) }\end{array}$ & -ve \\
\hline II $\mathbf{a}_{1}$ & -ve & II $b_{1}$ & -ve & III $_{1}$ & -ve \\
\hline II $\mathbf{a}_{2}$ & -ve & II $\mathbf{b}_{2}$ & -ve & III $_{2}$ & -ve \\
\hline II $\mathbf{a}_{3}$ & -ve & II $\mathbf{b}_{3}$ & -ve & $\mathrm{III}_{3}$ & -ve \\
\hline II $\mathbf{a}_{4}$ & -ve & II $\mathbf{b}_{4}$ & -ve & $\mathrm{III}_{4}$ & -ve \\
\hline
\end{tabular}

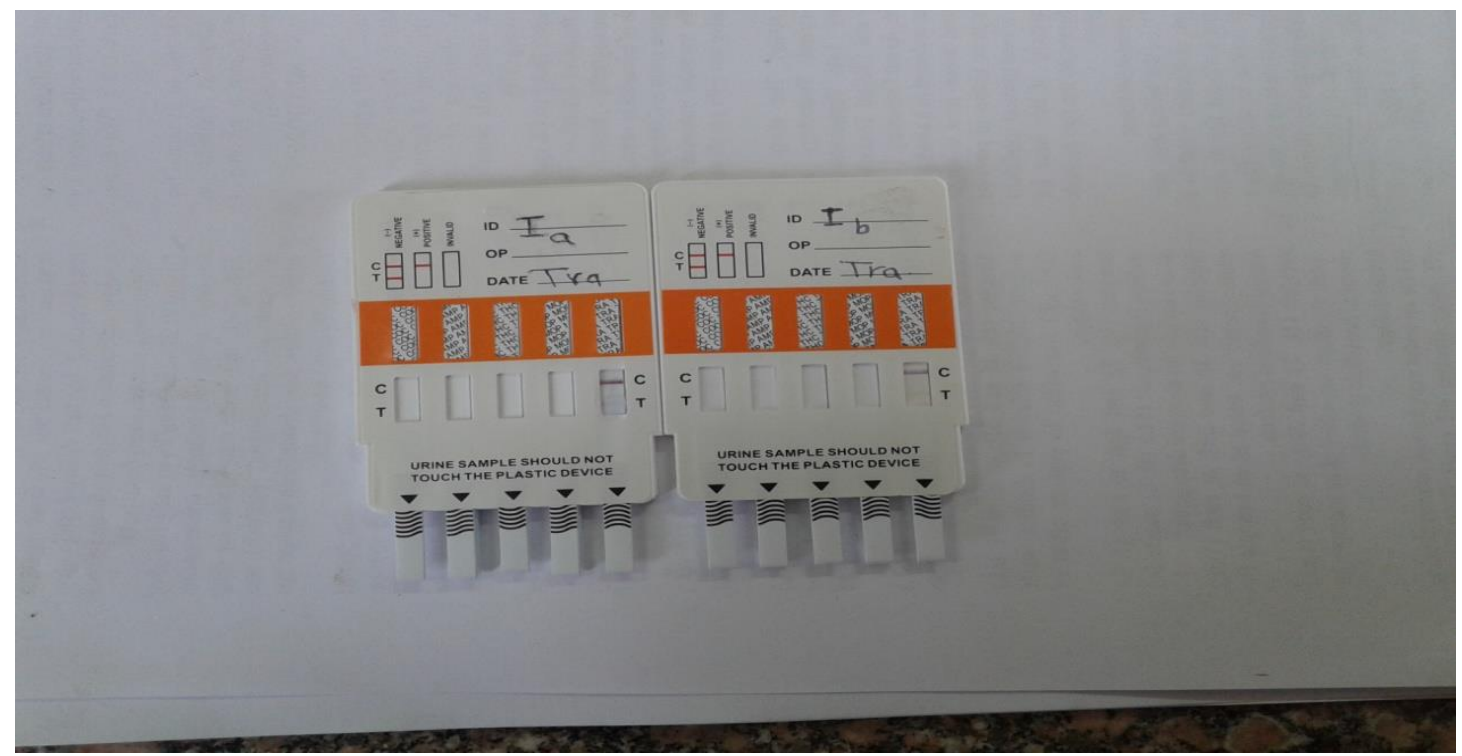

Fig 4: Drug of abuse test cards of group I (tramadol), (+ve) one line at C, regarding both concentrations $(200,400 \mathrm{ng} / \mathrm{ml})$. 


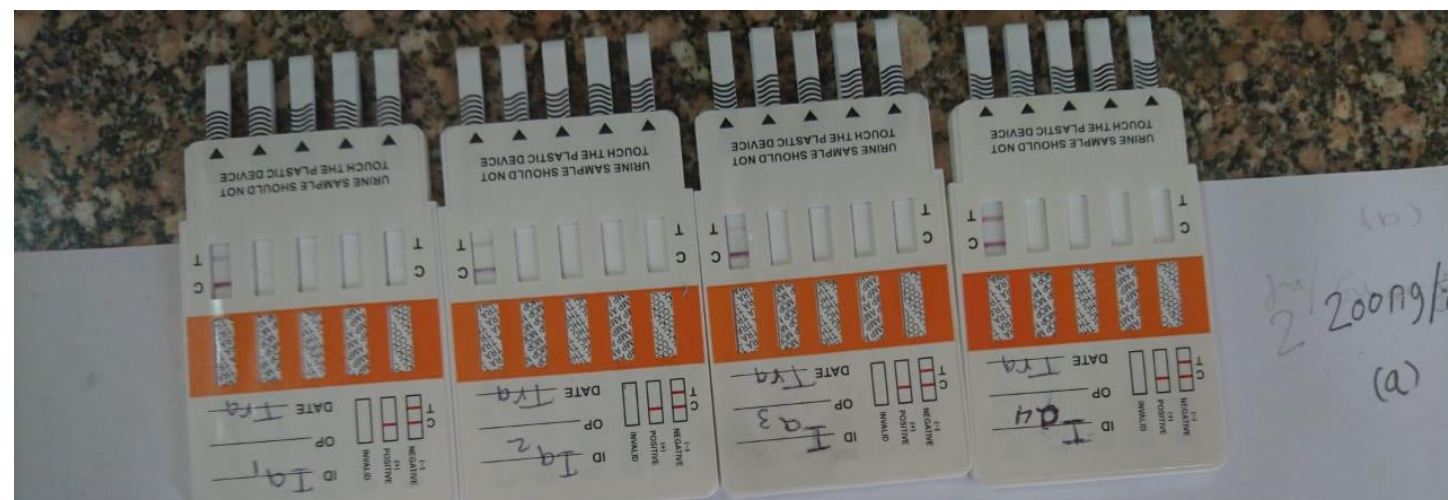

Fig 5: Drug of abuse test cards of group Ia (tramadol $200 \mathrm{ng} / \mathrm{ml}$ ), (-ve) one line at C and one line at $\mathrm{T}$ line.

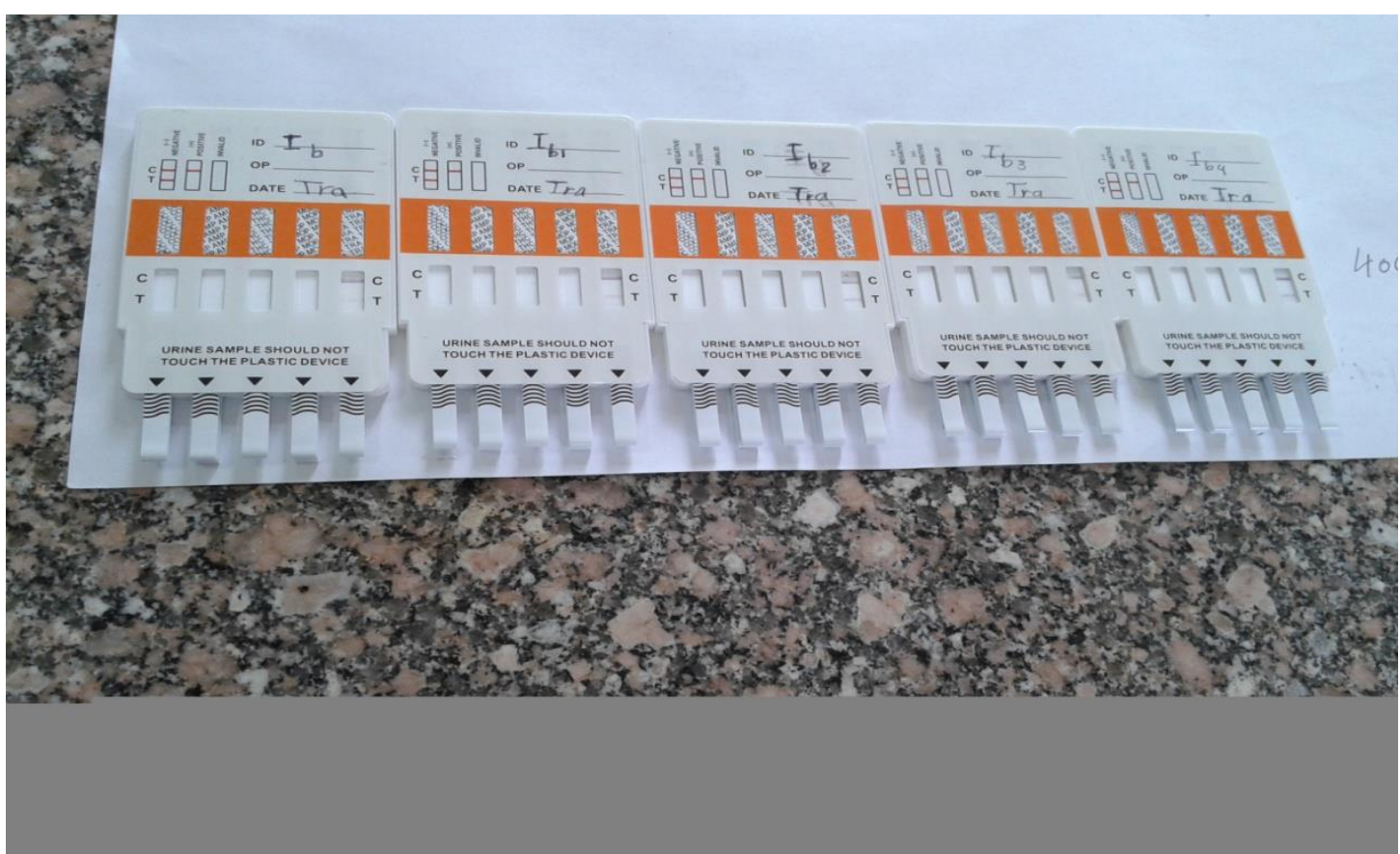

Fig 6: Drug of abuse test cards of group Ib (tramadol $400 \mathrm{ng} / \mathrm{ml}),(+\mathrm{ve})$ one line at C line, (-ve) one line at $\mathrm{C}$ and one line at $\mathrm{T}$ line. 


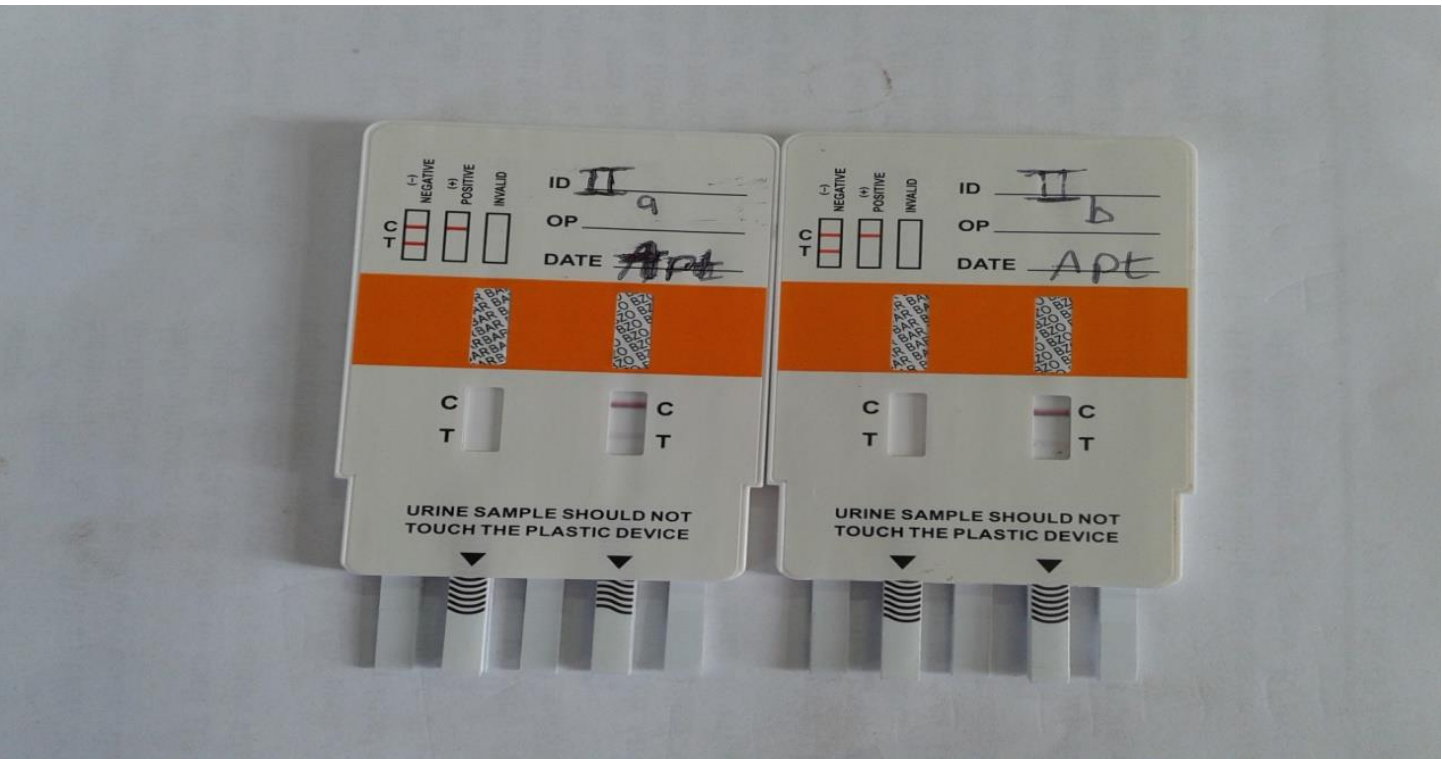

Fig 7: Drug of abuse test cards of group (II) apetryl, (+ve) one line at C, regarding both concentrations $(200,400 \mathrm{ng} / \mathrm{ml})$.

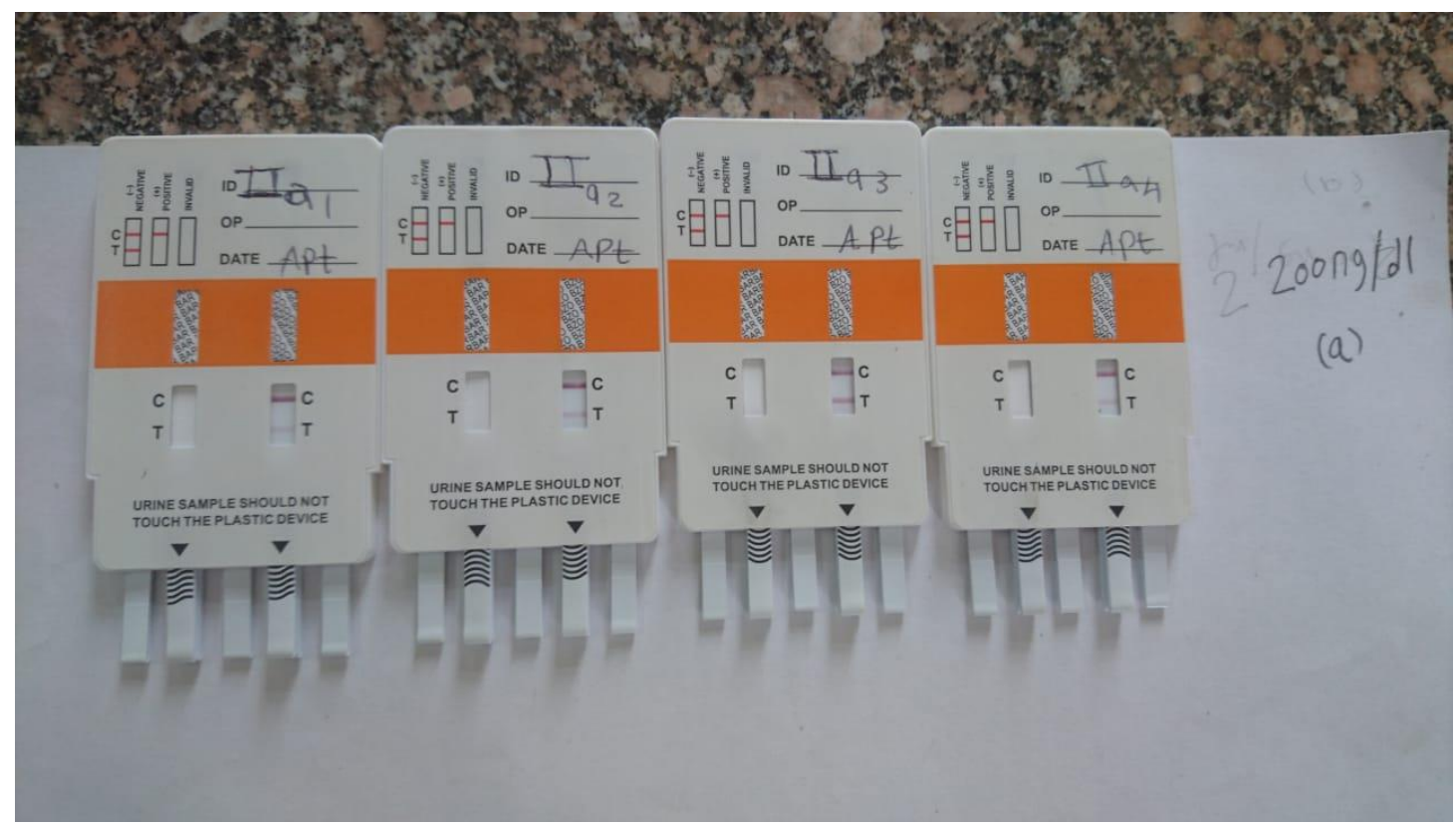

Fig 8: Drug of abuse test cards of groupII a (apetryl $200 \mathrm{ng} / \mathrm{ml}),(-\mathrm{ve})$ one line at C and one line at $\mathrm{T}$ line. 


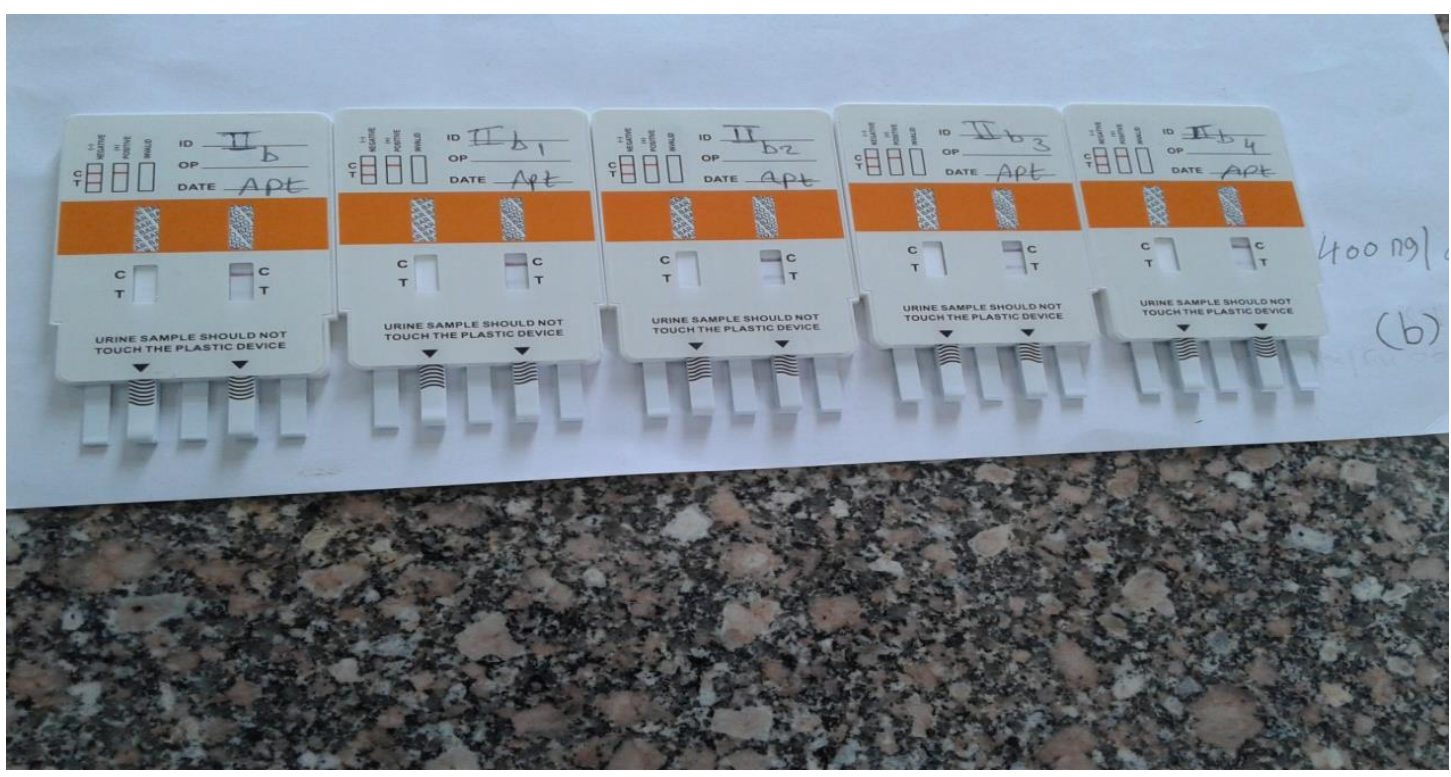

Fig 9: Drug of abuse test cards of group IIb (apetryl $400 \mathrm{ng} / \mathrm{ml}),(+\mathrm{ve})$ one line at C line, (-ve) one line at $\mathrm{C}$ and one line at $\mathrm{T}$ line.

\section{DISCUSSION}

In our study when we added the adulterants and did dilution for urine samples of control group, the results showed, orange coloration of $\mathrm{PH}$ paper test (about 4 on the scale) indicating more acidic $\mathrm{PH}$ with lemon juice, while visine, zinc sulfate and dilution gave light green coloration of $\mathrm{PH}$ paper test (about 5-6).

These results matching with Kerry et al., (2013) who reported that zinc sulfate (up to $50 \mathrm{mg} / \mathrm{mL}$ ) led to nonsignificant decrease in urine $\mathrm{pH}$, indicating that specimen validity testing is not effective in detecting adulteration of urine specimens with zinc sulfate.

In contrast to the results of this work, Ahmed et al., (2018) reported that the addition of zinc sulfate causes a measurable change in $(\mathrm{pH})$ relevant to successive increase in $\mathrm{Zn} \mathrm{SO} 4$ concentration; where $\mathrm{pH}$ value decreased from $6.5 \pm 0.02$ at zero concentration of $\mathrm{ZnSO} 4$ to a value of
$4.02 \pm 0.01$ at $100 \mathrm{mg} / \mathrm{ml}$ concentration of $\mathrm{ZnSO} 4$.

In this field, the ideal $\mathrm{pH}$ for of antigen -antibody complex (kit strip test) ranges between 6.5 and 7 . Change in $\mathrm{pH}$ (less than 5.0 or more than 9.5), will decrease the equilibrium constant of $\mathrm{Ag}-\mathrm{Ab}$ reaction equation 100 -fold lower than at 6.5-7. So, $\mathrm{pH}$ values (less than 5.0 or more than 9.5) induce marked changes in the shape of antibody molecule that might break down the complementarily with the antigen. So, urine $\mathrm{pH}$ cutoffs, less than 3 or more than 11 is considered as an indicator of adulteration of urine samples Cook et al., (2007).

In addition, when we added tramadol in both concentrations (200, $400 \mathrm{ng} / \mathrm{ml}$ ) to urine, the $\mathrm{PH}$ became about 6 , and when added apetryl in both concentrations $(200,400 \mathrm{ng} / \mathrm{ml})$ to urine, the $\mathrm{PH}$ became (about 7) on the scale. As well as, in this study when we used drug of abuse test cards in detecting tramadol $(200,400 \mathrm{ng} / \mathrm{ml})$ in urine adulterated with visine, $\mathrm{ZnSo} 4$ and lemon juice as well as diluted 
urine, the results were negative for all of them, the same results were with apetryl.

This was in agreement with Paul et al., (2000) who noticed considerable decrease in free morphine at a lower PH. In other research, Thabet et al., (2016) reported increase in the acidity causes highly significant reduction of the drug level, while increase in alkalinity causes apparent increase in drug level in case of high tramadol concentration.

In controversy to our result, Esposito et al., (2006) who reported that amphetamine, methamphetamine, codeine, morphine, and THC showed normal drug concentration in the basic urine when matched with the acidic urine, while benzoylecgonine, PCP, and 6-amphetamine showed decreased in concentration when urine $\mathrm{PH}$ increase (alkaline) when matched with the control urine. They referred these reductions in drug concentration to the increase in urine $\mathrm{PH}$.

Studies indicate that ingested zinc sulfate concentrations are $\sim 4200$ times lower than the effective adulterant concentrations (Lin \& Strathmann, 2013 ; Barrie et al., 1987).

Venkatratnam and Lents, (2011) reported that $\mathrm{Zn}$ induced potential false-negative results in drug testing whatever $\mathrm{Zn}$ was administered orally or was added invitro to urine samples. The mechanism of how zinc interacts with the components of the ELISA assay is obscure but as the zinc dose increased, the enhanced ELISA signal increases. Venkatratnam and Lents (2011) anticipated that zinc ion increases the binding of drug conjugate to which the active horseradish peroxidase enzyme is attached, hence raising the final signal. When zinc sulfate was added to urine samples, some urine samples showed signs of abnormal chromate ions level by using adultacheck10 urine test strips. However, when zinc was taken by ingestion, samples do not show signs of abnormal chromate ions level. On other hand, in this study when we added $\mathrm{ZnSo} 4$ directly to urine, turbidity was documented; this also was matched with Venkatratnam and Lents (2011).

As regard specific gravity measurement, in this study we found no effect of zinc sulphate, visin eye drop on sp. gravity values (1.025 for both), whereas lemon caused increase in the sp. gravity and diluted urine recorded decreased value (1.0301.015) respectively. This was keep matching with Jaffee et al., (2007) who declared that after water ingestion, positive drug test before fluid intake showed lowering in the concentrations of marijuana metabolites and cocaine metabolites below cutoff level $(50 \mathrm{mg} / \mathrm{mL}, 300$ $\mathrm{mg} / \mathrm{mL}$ ) respectively.

In the same words, Scholer, (2004) also agree with the present results and found that the most common and extensively documented method of manipulation is the dilution of the urine successful in connection with THC, producing an incorrect negative result.

Regarding eye drops, a decrease in the antigen concentration to below cut-off levels only at the $50 \% \mathrm{v} / \mathrm{v}$ level. However, these results could be a result of sample dilution of the specimen by the adulterant itself, and hence the drug within. Dilution decreases the amount of the antigen in the sample, which can produce a false negative (Olivieri et al., 2018).

The capability of eye drops to make false-negative results in the drug 
test screening is disturbing because this mean that the drug cannot be discovered by ordinary drug screening or routine specimen validity tests (Dasgupta, 2007).

Pearson et al., (1989) refer the mechanism of adulteration to benzalkonium chloride and borate found in eye drops. They reported that visine eye drops were effective in causing false negative results in the analysis of the THC metabolite, (THC$\mathrm{COOH})$. Using gas chromatography mass spectrometry (GC-MS) analysis showed no change in the structure of the THC metabolite by the components of eye drops.

At low concentrations of eye drops, the false-negative cannabinoid result was due to the benzalkonium chloride ingredient. Also, Jaffee et al., (2007) reported that visine is in causing false negative results in THC metabolites, but not other drugs, by different immunoassays. In this field, Mikkelsen and Ash, (1988) similar results benzodiazepines.

\section{CONCLUSION}

The current study concludes that adulterants make it easy to produce false negative results and the specimen integrity testing is inadequate in detection of these adulterants.

\section{RECOMMENDATIONS}

It is important to find a more efficient method that can detect the drugs or their metabolites as well as zinc and other adulterants in urine samples. Detection of these substances in urine samples makes the evidence of adulteration very clear.

\section{REFERENCES}

Abdel-Gawad, T.M. (2008): "Facts of drug abuse in Egypt" http://www.isamweb.com/pages/p dfs/ebook\%20Issue\%203/Gawad.p df

Ahmed, M.G.; El-Sherify, S. and Abdel Azim, A.M. (2018): Interference of zinc sulphate with tramadol and diazepam immunoassay testing. International journal of research granthaalayah , 6(9):326-331. https://doi.org/10.5281/zenodo.14 43498.

Barrie SAW, J.V.; Pizzorno, J. E.; Kutter, E. and Barron, P.C. (1987): Comparative absorption of zinc piconate, zinc citrate and zinc gluconate in humans. Agents Actions, 21(1/2): 223-8.

Cody, J.T. and Schwarzhoff , R.H. (1989): Impact of adulterants on RIA analysis of urine for drugs of abuse. Journal of Analytical Toxicology,13:277-287.

Cook, J. D.; Strauss, K. A.; Caplan, Y. H.; Dico, C. P. and Bush, D. M.(2007): Urine $\mathrm{pH}$ : the effects of time and temperature after collection. Journal of Analytical Toxicology, 31(8):486-496.

Dasgupta, A. (2007): The effects of adulterants and selected ingested compounds on drugs of abuse testing in urine. American Journal of Clinical Pathology, 128:491503. doi: 10.1097/FTD.0000000000000174.

Drug Bank: Record Name: Clonazepam

URL:http://www.drugbank.ca/dru gs/DB01068.

Esposito, F.M.; Mitchell, J.M.; Baylor, M.R. and Bush, D.M. (2006): Influence of basic $\mathrm{pH}$ on federal regulated drugs in urine at room temperature. Presented as a 
poster at the SOFT Annual Meeting, Austin,TX

Fu, S. (2016): Adulterants in urine drug testing. Advances in Clinical Chemistry, 76:123-163.

Grange, R.D.; Thompson, J.P., and Lambert, D.G. (2014): Radioimmunoassay, enzyme and non-enzyme-based immunoassays. British Journal of Anaesthesia, 112:213-216.

Grond, S. and Sablotzki, A. (2004): "Clinical pharmacology of tramadol". Clinical Pharmacokinetics. 43 (13): 879923. doi: $10.2165 / 00003088-$ 200443130-00004.

PMID 15509185.

Huestis, M.; Mitchell, J. and Cone, E. (1995): Detection times of marijuana metabolites in urine by immunoassay and GC-MS. Journal of Analytical Toxicology, 19:443-449.

Jaffee, B. W.; Trucco, E.; Levy, S. and Weiss, R. D. (2007): Is this urine really negative? A systematic review of tampering methods in urine drug screening and testing. Journal of Substance Abuse Treatment, 33: $33-42$.

Karhu D, El-Jammal A, Dupain T, Gaulin D, Bouchard S (2007): "Pharmacokinetics and dose proportionality of three Tramadol Contramid OAD tablet strengths". Biopharmaceutics \& Drug Disposition. 28 (6): 323-30. doi:10.1002/bdd.561.

PMID 17575561.

Kerry, J.; Welsh Jennifer, E.; Dierksen, K. and Dasgupta, A. (2013): Novel Spot Tests for Detecting the Presence of Zinc Sulfate in Urine, a Newly
Introduced Urinary Adulterant to Invalidate Drugs of Abuse Testing. American Journal of Clinical Pathology, 140(4): 572578 , https://doi.org/10.1309/AJCP2FJ9 VBPXJYTQ

Lee, S.F.; Hsu, J.; Tsay, W.I. (2013): The trend of drug abuse in Taiwan during the years 1999 to 2011 Journal of Food and Drug Analysis, 21: 390-396.

Lin, C.N. and Strathmann, F.G. (2013): Elevated urine zinc concentration reduces the detection of methamphetamine, cocaine, THC and opiates in urine by EMIT. Journal of Analytical Toxicology, 37(9): 665-9.

Mikkelsen, S.L. and Ash, K.O. (1988): Adulterants causing false negatives in illicit drug testing. Clinical Chemistry, 34:2333-2336.

Moeller, K.E.; Lee, K.C. and Kissack, J.C. (2008): Urine Drug Screening. Mayo Clinic Proceedings, 83:66-76.

Needleman SB, Porvaznik M. (1995): Identification of parent benzodiazepines by gas chromotography/mass

spectroscopy (GC/MS) from urinary extracts treated with Bglucuronidase. Forensic Science International, 9; 73(1):49-60.

Nordal, K.; Øiestad, E.L.; Enger, A.; Christophersen, A.S. and Vindenes, V. (2015): Detection Times of Diazepam, Clonazepam, and Alprazolam in Oral Fluid Collected From Patients Admitted to Detoxification, After High and Repeated Drug Intake. Therapeutic Drug Monitoring, 37(4):451-60. 
Olivieri, B.; Marić, M. and Bridge, C. (2018): Determining the effects of adulterants on drug detection via enzyme-linked immunosorbent assay and adulterant tests strips. Drug Testing and Analysis, 10:1383-1393.

Paul, B.D.; Martin, K.K.; Maguilo, J. Jr. and Smith, M. L. (2000): Effects of pyridinium chlorochromate adulterant (Urine Luck) on testing of drugs of abuse and a method for quantitative detection of chromium (VI) in urine. Journal of Analytical Toxicology, 24:233-237.

Pearson, S.D.; Ash, K.O. and Urry, F.M. (1989): Mechanism of falsenegative urine cannabinoid immunoassay screens by Visine eye drops. Clinical Chemistry, 35:636-638.

Scholer, A. (2004): The effect of urine manipulation on substance abuse testing. T + K .71 (3): 127.

Schütz, H.; Paine, A.; Erdmann, F.; Weiler, G. and Verhoff, M.A. (2006): Immunoassays for drug screening in urine. Forensic Science, Medicine and Pathology, 2:75-83.

Thabet, H.Z.; Mohamed, A.A. and Abd-El-hameed, S.Y. (2016): Effect Of Some Methods Of Adultration On Tramadol Detection In Urine By Drug Of Abuse Test Cards And Immunoassay. Zagazig Journal of Forensic Medicine \& Toxicology,14 (1): 29- 41.

Tjäderborn, M.; Jönsson, A.K.; Hägg, S. and Ahlner, J. (2007): Fatal unintentional intoxications with tramadol during 1995-2005.
Forensic Science International. 173 (2-3): 107-11. doi:10.1016/j.forsciint.2007.02.00 7. PMID 17350197.

Venkatratnam, A. and Lents, N.H. (2011): Zinc Reduces the Detection of Cocaine,Methamphetamine, and THC by ELISA Urine Testing. $\mathbf{J}$ Anal Toxicology, 35: 333-40.

Verstraete AG. (2004): Detection times of drugs of abuse in blood, urine, and oral fluid. Ther Drug Monitoring, 26:200-205.

Walsh, M. (2008): New technology and new initiatives in U.S. workplace testing. Forensic Science International, 174: 120124. 


\section{الملخص العربي}

تأثير الزنك وبعض المنتجات التجاريه على الكثف عن الترامادول والإبيتريل فى عينات البول

$$
\text { شيرين أحمد الخطيب ، منار حامد عرفه }
$$

\section{قسم الطب الثرعى و السموم الاكلينيكية كلية الطب البشرى- جامعة الزقازيق ـ مصر}

يلعب اختبار البول للمخدرات دوراً هاماً في الكثف عن تعاطي المخدرات بصورة مشروعة وغير مشروعة و

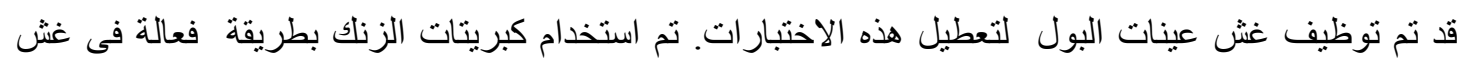

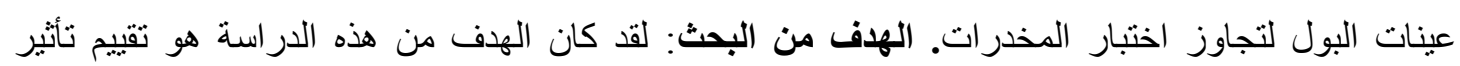
كبريتات الزنك وبعض طرق الغش فى الكثف عن الترامادول والأبتريل في البول و آثارها على اختبارات

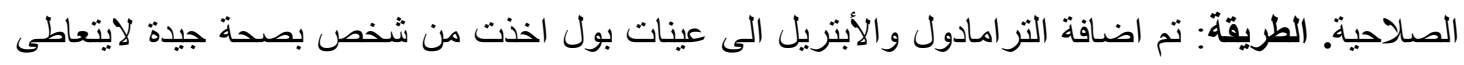
المخدرات و لكى نحصل على عينات بول تحتوى على الترامادول و الابتريل بالتركيزات الاتية (200، 400

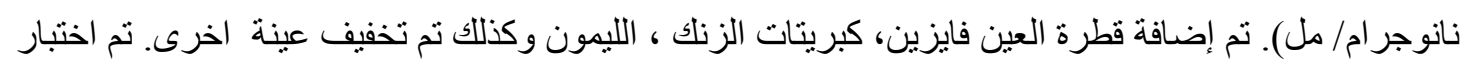

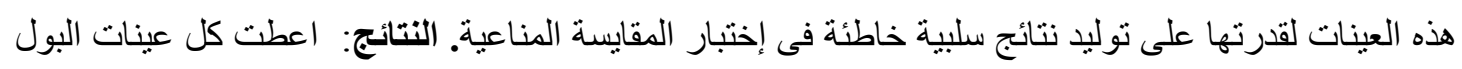

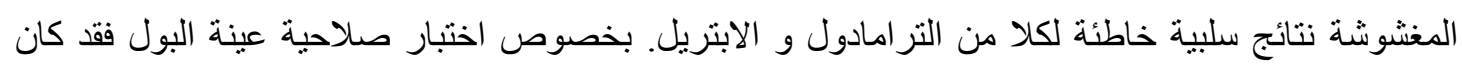

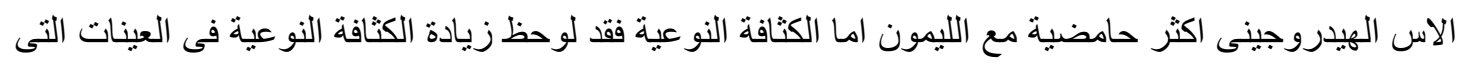
تم غشها بالليمون بينما قلت فى العينات المخففة. الاستنتاج: هناك حاجة إلى اتباع نهج أكثر فعالية وكفاءة لتحليل البول بسبب النتائج السلبية الكاذبة التي يمكن أن تنتج عن غش عينات البول. التوصيات: تطوير طريقة بسيطة

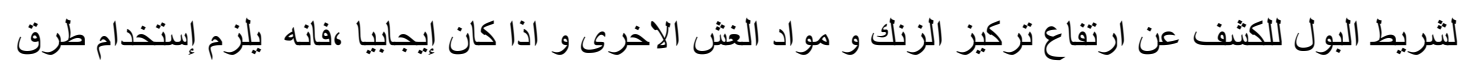
اخرى (أكثر فعالية) للكثف عن المخدر ات مثل كروماتو غر افيا الغاز ــ مطياف الكتلة. 